\title{
Microanatomical development of the equine kidney and defects associated with intra-uterine growth retardation
}

\author{
Nicola B. Holdstock, P. D. Rossdale, D. J. Beech, Tahera Ansari and P. D. Sibbons \\ Department of Clinical Veterinary Medicine, Cambridge University, Madingley Road, Cambridge
}

\begin{abstract}
Summary
Using novel stereological techniques, this study attempts to establish normal organogenesis of the equine kidney in utero and into the post partum period, and the effects of adverse intra-uterine conditions on fetal development. At birth, renal maturation appears to be more advanced in Ponies compared to Thoroughbreds (TB's), and the study has highlighted differences in normal kidney development between native Ponies and "un-naturally" selected TB's. The data presented supports previous physiological studies. Results also showed that compared to other species, organ development continues for a relatively longer time postnatally in the horse. Until completion of organogenesis the horse may be at risk of exceeding its functional capacity especially during periods of stress or excessive physiological demands which are placed on the developing racehorse. Altered/deficient organogenesis seen in the intra-uterine growth retarded (IUGR) animals may help to explain some of the physiological incompetence and the increase in morbidity and mortality seen in this group of animals by equine clinicians.

Keywords: $\quad$ foal, kidney, organogenesis, growth retarded

Mikroanatomische Entwicklung der equinen Niere und Defekte, die mit einer intrauterinen Wachstumsverzögerung assoziiert sind

Diese Untersuchung versucht mit Hilfe neuer stereologische Methoden die normale Organogenese der equinen Niere in utero und bis in die postpartale Zeit zu beschreiben und die Auswirkungen ungünstiger Einflüsse auf die fetale Entwicklung zu ermitteln. Zum Zeitpunkt der Geburt scheint die Reife der Niere bei Ponies im Vergleich zu Vollblütern weiter fortgeschritten zu sein, so dass Unterschiede bei der normalen Entwicklung der Niere zwischen den ursprünglichen Ponies und den hochgezüchteten Vollblütern nachgewiesen werden konnten. Die präsentierten Ergebnisse unterstützen frühere Studien über die Physiologie. Die Ergebnisse zeigen auch, dass die Organentwicklung im Vergleich zu anderen Spezies für einer längere Zeit post natum andauert. Bis zur Vollendung der Organogenese besteht die Gefahr, dass die funktionelle Kapazität der Organe überschritten wird. Dies kann durch Stress oder zu hohe physiologische Anforderungen bei sich noch entwickelnden Rennpferden geschehen. Veränderte / ungenügende Organogenese, wie sie bei der intrauterinen Wachstumsverzögerung (IUGR) auftreten, können zum Verständnis der bei diesen Tieren klinisch beobachteten physiologischen Inkompetenz und erhöhten Morbidität und Mortalität beitragen.
\end{abstract}

Schlüsselwörter: Fohlen, Niere, Organogenese, Wachstumsverzögerung

\section{Introduction}

The effects of adverse intra-uterine conditions on fetal development have been well documented in man with regard to intra-uterine growth retardation (IUGR), sudden infant (cot) death syndrome (SIDS), and diseases occurring in later life e.g. coronary heart disease, asthma, diabetes (Buck et al., 1989). In man, IUGR has been defined when an infant is born at a birth weight significantly below (10 th percentile) the mean for gestation, irrespective of any clinical features shown (Battaglia and Lubchenco, 1967). In spite of the absence of macroscopic organ defects, stereological techniques have revealed important micro-anatomical deficiencies and, in particular, glomerular number in the kidneys of infants suffering from IUGR and SIDS (Hinchliffe et al., 1992, 1993).

Little is known about normal renal organogensis in the horse and stereological techniques are novel in their application to equine tissue. Directly correlating structure to function is unique for any species and will provide further understanding of renal development during gestation and in the post partum period, and defects associated with IUGR to be determined. Future development of prognostic tests for micro-anatomical deficits in renal development will have implications for subsequent survival, growth and athletic performance.
Aims
i) To determine normal micro-anatomical development of the Pony and Thoroughbred (TB) kidney
ii) To correlate the above anatomical findings to previous functional tests of the equine kidney
iii) To establish any micro-anatomical deficits in the kidneys of IUGR TB foals

\section{Materials and methods}

For consistency, the left kidney was collected from 62 horses (Control Ponies n=24; Control TB's n=32; IUGR TB's $n=6$ ), 
ranging from 60 days gestation to 8 months post partum. The IUGR animals were defined using parameters previously described in infants (Battaglia and Lubchenco, 1967). Using design-based, unbiased stereological techniques (Hinchliffe et al., 1993), whole kidney and cortex volume, total glomerular number and glomerular volume were determined. Functional tests, including amniotic and allantoic fluid analysis, inulin/paraaminohippuric acid and fractional excretion of electrolytes, have already been performed (Holdstock, 1995), and were correlated to the stereological findings of the kidneys.

\section{Results}

Stereological data are presented in absolute values, Figures $1-4$, rather than in values per kilogram body weight because no significant differences were seen when factored for body weight except for glomerular volume values.

\section{Kidney volume and cortex volume (Figures 1 and 2)}

These parameters increased with an increasing post conceptual age in both breeds. In early to mid gestation kidney development

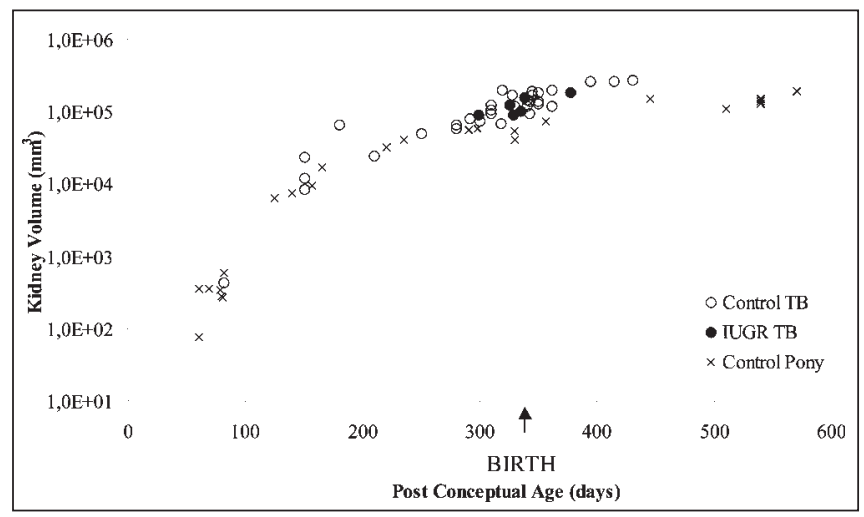

Fig. 1: Kidney Volume $\left(\mathrm{mm}^{3}\right.$ ) Against Post Conceptual Age (days) in the Horse

Nierenvolumen $(m m \approx)$ in Abhängigkeit vom Alter post conceptionem (Tage) beim Pferd

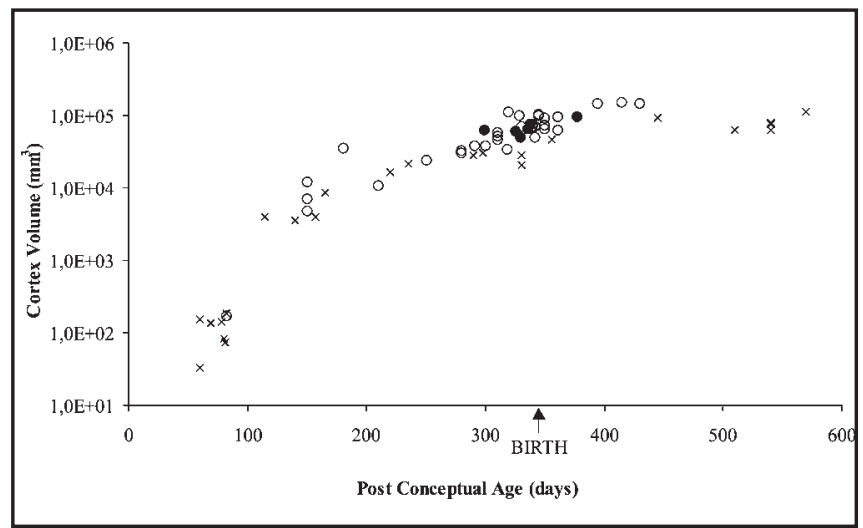

Fig. 2: Cortex Volume $\left(\mathrm{mm}^{3}\right)$ Against Post Conceptual Age (days) in the Horse

Nierenrindenvolumen ( $\mathrm{mm} \approx)$ in Abhängigkeit vom Alter post conceptionem (Tage) beim Pferd in Ponies and TB's appeared to be similar, whereas by late gestation the rate of increase in Ponies slowed down sooner, and at a lower value, than that of TB animals. The IUGR group appeared to fall within the normal TB range for both parameters.

\section{Glomerular number (Figure 3)}

There was an increase in glomerular number with post conceptual age in both breeds, although the rate of increase appeared to level off sooner, and at a lower value, in Ponies where glomerular number increased from $9.18 \times 10^{3}$ at 60 days gestation to a plateau of $3.62 \times 10^{6}$ at 250 days gestation, whereas in TB's glomerular number increased from $1.66 \times 10^{4}$ at 82 days gestation to a plateau of $8.75 \times 10^{6}$ around 2 months post partum. The values for the IUGR TB group were within the normal TB range.

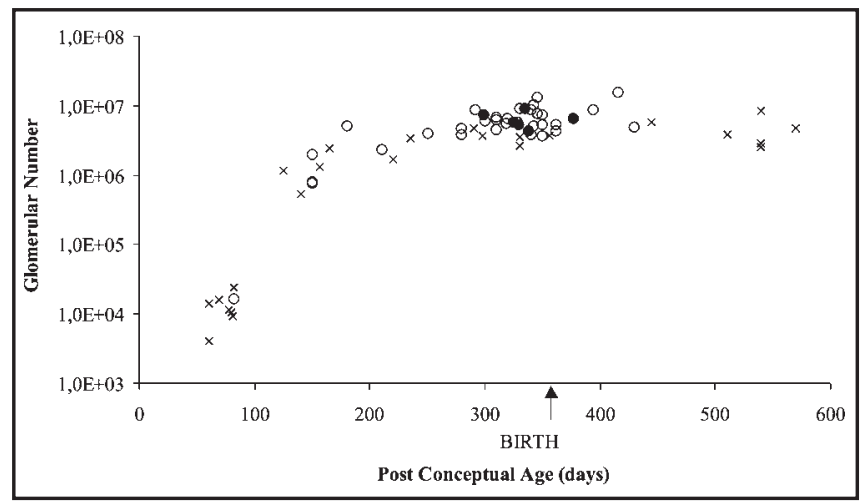

Fig. 3: Glomerular Number Against Post Conceptual Age (days) in the Horse

Anzahl Glomerula in Abhängigkeit vom Alter post conceptionem (Tage) beim Pferd

\section{Glomerular volume (Figure 4)}

The profile of glomerular volume development appeared to be similar throughout the time of study for both breeds. Glomerular volume decreased in Ponies and TB's from $8.78 \times 10^{5} \mu^{3}$ and $1.25 \times 10^{6} \mu^{3}$, respectively, at 80 days gestation, to $2.19 \times 10^{5}$

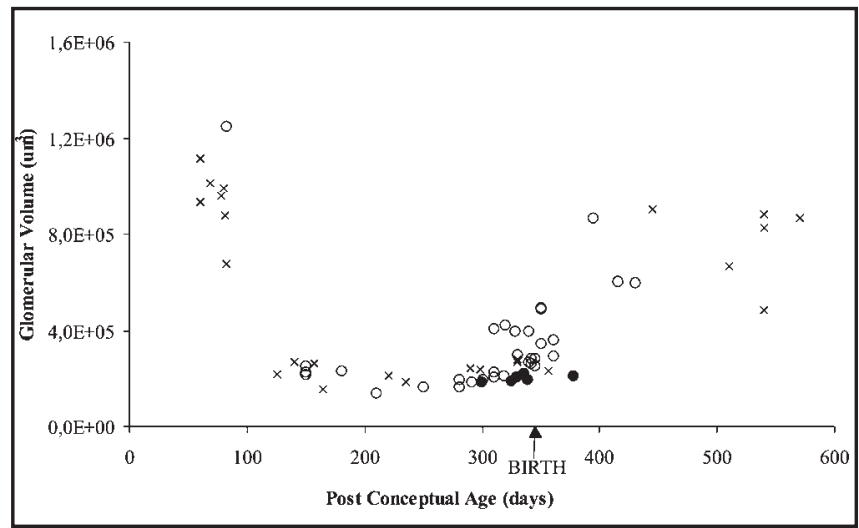

Fig. 4: Glomerular Volume $\left(\mu \mathrm{m}^{3}\right)$ Against Post Conceptual Age (days) in the Horse

Volumen der Glomerula ( $\mu \mathrm{m} \approx$ ) in Abhängigkeit vom Alter post conceptionem (Tage) beim Pferd 
$\mu \mathrm{m}^{3}$ and $2.28 \times 10^{5} \mu^{3}$, respectively, at 150 days gestation, and then increased around birth to reach a plateau of $8.65 \mathrm{x}$ $10^{5} \mu^{3}$ and $8.68 \times 10^{5} \mu^{3}$, respectively, at 2 months post partum. Unlike the above parameters, the IUGR TB foals had reduced ( $p<0.0015$, MannWitney $U$ test) median absolute glomerular volume values compared to the control TB group $\left(2.0 \times 10^{5} \mu^{3}\right.$, and $2.9 \times 10^{5} \mu^{3}$, respectively) when compared for the same post conceptual and post natal age ranges. When factored by bodyweight, although the median IUGR foal values remained lower than the controls $\left(5258.5 \mu^{3}\right.$ and $5707.1 \mu^{3}$, respectively) the difference was no longer significant ( $p=0.35)$.

\section{Discussion}

Although the number of kidneys included in this study was limited, because the range of antenatal and post natal development was examined, the data gained has provided important information regarding normal micro-anatomical development in the horse. In the early gestation there are no comparable studies available in other species. However, renal organogenesis has been shown to stop in utero or around birth in most species studied (Hinchliffe et al., 1991; Bains et al., 1996), whereas kidney development in the horse appeared to continue for a relatively longer time in the postnatal period. Until completion of organogenesis the horse may be at risk of exceeding its functional capacity, an important factor to consider for the racing Thoroughbred.

In early to mid gestation renal development appears similar for the 2 breeds. Correlating the structural findings to previous functional tests of the equine kidney showed that the greatest developmental changes in glomerular number and volume occurred when fetal urine was first detected in the allantoic fluid at approximately 150 days in Ponies and TB's (Holdstock, 1995). At birth, renal micro-anatomical maturation appeared to be more advanced in Ponies when compared to TB's, which has also supported previous physiological studies (Holdstock, 1995). The

Tab. 1 : Information on disturbances of pregnancy for the IUGR Foals Informationen über die Trächtigkeitsprobleme bei den IUGR Fohlen

\begin{tabular}{|l|l|l|l|}
\hline Case & $\begin{array}{l}\text { Post Concep- } \\
\text { tual Age }\end{array}$ & Disturbances in pregnancy & Placentitis \\
\hline 1 & 377 days & $\begin{array}{l}\text { Mare ran milk for 5 weeks } \\
\text { before foaling }\end{array}$ & $?$ \\
\hline 2 & 325 days & $\begin{array}{l}\text { îRed bagî presentation at } \\
\text { delivery, premature placental } \\
\text { separation }\end{array}$ & YES \\
\hline 3 & 338 days & NO & NO \\
\hline 4 & 335 days & $\begin{array}{l}\text { All of these were Pony mares } \\
\text { which had been given a TB } \\
\text { embryo by embryo transfer } \\
\text { and, therefore, were thought } \\
\text { to have restricted utero/pla- } \\
\text { cental development during } \\
\text { pregnancy (Allen et al., 1999) }\end{array}$ & NO \\
\hline 5 & 299 days & & NO \\
\hline 6 & 329 days & NO \\
\hline
\end{tabular}

present study has highlighted differences in normal kidney development between native Ponies and "un-naturally" selected TB's. It would appear that micro-anatomical deficits may occur in the kidneys of the IUGR TB foals, although the small number of IUGR foals involved in this study, and the lack of accurate corresponding controls, made interpretation of the significance of the differences difficult between the 2 groups. Data suggested that IUGR foals had deficiencies in glomerular volume, rather than reduced glomerular number seen in IUGR animals of other species (Hinchliffe et al., 1992; Bains et al., 1996). As in IUGR infants (Barker, 1994), altered/deficient organogenesis may help to explain some of the physiological incompetence seen in IUGR foals. Victims of SIDS are born without spare capacity in their organs and when they become stressed or either sub-clinically or clinically ill, they are not able to call on reserve capacity to compensate for compromise of normal function.

The placenta, as the major organ responsible for oxygen and nutrient delivery to the developing fetus, plays a crucial role in maintaining an adequate homeostatic environment in utero. Of the 6 IUGR animals studied, 5 had known in utero disturbances (Table 1). It is hypothesised that placental insufficiency is the most likely condition to result in altered organogenesis in these animals. However, it is possible that the continued postnatal development in the horse may allow neonatal compensations for intra-uterine problems, thereby being a possible mechanism of repair/regeneration for disturbances in pregnancy. Further work is proposed to follow up these hypotheses.

\section{Literature}

Allen, W. R., Wilsher, Sandra., Barrett, K., Stewart, Francesca., Fowden, Abby., Ousey, Jenny., Rossdale, P. D. (1999): Havemeyer Foundation Monograph Series No 2, 49-51

Bains, R. K., Sibbons, P. D., Murray, R. D., Howard, C. V., van Velzen, D. (1996): Stereological estimation of the absolute number of glomeruli in the kidneys of lambs. Res Vet Sci 60, 2, 122-125

Barker, D. J. P. (1994): Mothers, babies and diseases in later life (the undernourished baby) Br Med J 1, 121-138

Battaglia, F. C., Lubchenco, L. O. (1967): A practical classification of new born infant by weight and gestational age. J Pediatr 71, 159-167

Buck, G. M., Cookfair, D. L., Michalek, A. M., Nasca, P. C., Standfast, S. Y., Sever, L. E., Kramer, A. A. (1989): Intra uterine growth retardation and risk of sudden infant death syndrome (SIDS). Am J Epidem 129, 874-884

Hinchliffe, S. A., Howard, C. V., Lynch, M. R., Judd, B. A., van Velzen, D. (1993): Renal develpmental arrest in SIDS. Paediatr Pathol 13, 333-343 Hinchliffe, S. A., Lynch, M. R. J., Sargent, P. H., Howard, C. V., van Velzen, D. (1992): The effect on intrauterine growth retardation on the development of renal nephrons. Br J Obs Gyn 99, 296-301

Hinchliffe, S. A., Sargent, P. H., Howard, C. V., Chan, Y. F., van Velzen, D. (1991): Human intrauterine renal growth expressed in absolute number of glomeruli assessed by the Disector method and Cavalieri principle. Lab Invest 64, 6, 777-784

Holdstock Nicola. B. (1995): Electrolyte and water homeostasis in the perinatal foal. PhD Thesis, University of Cambridge

Nicola B. Holdstock, Dr, MA, Vet.MB, PhD, Cert.EM.(Stud Med), MRCVS

Department of Clinical Veterinary Medicine, Cambridge University Madingley Road

Cambridge CB3 OES, UK

Tel: 01223330845

Fax: 01223330886

e-mail:nbh10@cam.ac.uk 